\title{
Police Role In The Handling Of Hate Speech
}

\section{Zaldy Kurniawan ${ }^{1}$}

Abstract. Development and advancement of technology in Indonesia is a form of improving the quality and quantity of human resources. Along with it, the technological advances giving positive and negative impacts on the nation Indonesia. As one of the negative impacts are increasingly banyakannya cyber crimes occurred. Of hate speech as one example of crime that can break the unity of the nation. Thus takes the role of the Police in order to make prevention and law enforcement against the emergence of hate speech in cyberspace. The current legal regulations still need to be updated to support the performance of the police. The role of the Government to promote prevention efforts are also expected to prevent the speech of hatred in the society.

Keywords: Role of Police, Handling, Hate Speech.

\section{Introduction}

The development of information technology is already highly sophisticated, fast and easy, so that a way of life (life style) for people around the world is no exception in Indonesia was also affected by the development of information technology in the era of globalization. One of the utilization of information technology with the emergence of a wide variety of social networking sites is spread to a wide range among children, students, housewives, economy top to the down economy, and many others can use social networking sites to the needs of each users. ${ }^{2}$

The information and communication technology also has changed the behavior of human society and civilization globally. ${ }^{3}$ With the advent of the Internet, there is a new kind of world that had not previously been known to man, the world of the so-called virtual world? The advent of virtual world has changed the habits of many people, especially in their lives accustomed to using the internet. Starting from changing the ways and means of business transactions or banking transactions are done using the Internet takes place in a virtual world called the electronic transactions (electronic transactions or e-commerce), education (electronic education), health (tele-medicine), transportation, the tourist industry, the environment, to the entertainment sector.

Despite widespread use of the internet is on one side brings a positive change in the field of life, political, social, economic and so on. But on the other hand lead to a paradigm shift in the study of crime. ${ }^{4}$ The negative impact is often the case with ease to communicate and exchange information through social networking sites among users of social networking is to spread a message that has a charge of insult or defamation, which was

\footnotetext{
1 Student of Masters (S2) of Law Faculty of Law Unissula Semarang email: zaldykurniawan2008@gmail.com

2 Budi Suhariyanto 2014 Tindak Pidana Teknologi Informasi (Cybercrime) Raja Grafindo Persada Jakarta p. 2.

${ }^{3}$ Ahmad M. Ramli 2004 Cyber Law and Intellectual Property in the Indonesian Legal System Rafika Aditama Jakarta p. 1.

${ }^{4}$ Ahmad M. Ramli 2004 Cyber Law dan HAKI dalam Sistem Hukum Indonesia Rafika Aditama Jakarta p. 201.
} 
originally the owner of the account has only wanted to write what he thinks on account status social networks that he had. However, one often forgets that he wrote the words that can be read by all those who also have a social networking account.

In these circumstances the act can enter into the act a crime, because the status he wrote containing the speech of hatred (Hate Speech) which can be read by many people. To that end, the government itself has regulated Act No. 11 Of 2008 on Information and Electronic Transactions. ${ }^{5}$

Legal arrangements regarding Hate Speech in Indonesia is not yet clear and unequivocal as in other countries such as Australia, Canada and New Zealand. However, some human rights instruments and the Constitution provided has given legal protection against this problem, although not comprehensive and widely received less attention. ${ }^{6}$

Associated with the norms of the functions and objectives of the Police, Article 2 of Act No. 2 of 2002 on the Indonesian National Police stated that the function of the police is one of the functions of state government in maintaining security and public order, law enforcement, protection, shelter, and services to community. Then in Article 4 reaffirmed Police aims to achieve internal security, which includes maintenance of public order and security, order and the rule of law, the implementation of protection, shelter, and service to the community, as well as public tranquility to uphold human rights.

In addition, the police state apparatus that play a role in maintaining security and public order, enforcing the law, and to provide protection, shelter and services to the community in order to maintaining security in the country. ${ }^{7}$

In order to perform their function and their aims, associated with the handling action utterances of hate going on in the community, the police use the Act ITE (Information and Electronic Transaction) as a reference once technical instructions or guidelines for the handling of the actions associated with the speech of hate to do preventive measures (preventive) and law enforcement (repression).

Based on the background of the problems described above, the formulation of a problem that can be asked is how the role of the national police in the handling of hate speech (hate speech)?

\section{Result And Discussion}

After the reform and the 1945 amendments open the widest access for the public to participate in government, especially through the guarantee of freedom of speech. This gives euphoria for the public to express any opinion in various media of communication, both verbally and in writing. The euphoria of freedom of speech increasingly felt by the public since the arrival of the internet. People can easily express and convey their opinions through the means of the Internet, one form of social media.

Social media has become part of people's daily life and activities to do community through

\footnotetext{
${ }^{5}$ Act No. 11 of 2008 on Information and Electronic Transactions General provisions.

${ }^{6}$ Article 20 Act No. 12 of 2005 concerning the Ratification of the International Covenant On Civil Rights and Politics.

${ }^{7}$ Article 5 (1) and Article 13 of Act No. 2 of 2002 on the Indonesian National Police.
} 
social media, namely: ${ }^{8}$

- To channel private to public opinion.

- Is a means to run a business, as promotional efforts.

- Effective as a means of provocation and publications.

The relevance of the internet and freedom of expression Frank William La Rue that the Internet is a medium that can become an important tool in the fulfillment of the right of speech and expression. ${ }^{9}$ This view is also supported by Yanuar Nugroho said that the Internet provides an opportunity for individuals to express their opinions and aspirations, even getting a response in ways previously unimaginable. ${ }^{10}$

The euphoria in the enjoyment of the freedom of expression was not accompanied by their understanding of the essence of freedom of speech and a sense of responsibility in the implementation. The community is only focusing on its right to hold opinions and to forget his duty in using the his opinion rights. Besides the weakness in the use of social media in Indonesia is also caused by a lack of understanding of ethics in social mediated expression, and the lack of firmness of government and law enforcement agencies on cases that occur in social media. This can be demonstrated by the many cases of hate speech on the hoax and that is done through social media

A speech of hatred is an act of communication made by an individual or group in the form of provocation, incitement, or insults to individuals or other groups in terms of various aspects such as race, color, ethnicity, gender, disability, sexual orientation, nationality, religion, and etc. The attention to the speech of hatred (Hate Speech) in the international community can be seen from the enactment of a number of international instruments relating to the speech of hatred (Hate Speech). Some are calling the prohibition against hateful speech (Hate Speech) can be encountered in: ${ }^{11}$

- 1948 United Nations Declaration of Human Rights.

- The UN 1965 International Convention on the Elimination of All Forms of Racial Discrimination (Convention On The Elimination Of All Forms Of Racial Discrimination / CERD).

- The 2002 United Nations Program of Action of the World Conference Against Racism, Racial Discrimination, Xenophobia and Related Intolerance / CERD.

- OSCE in 2016, SOVA Center for Information and Analysis Alexander Verkhovsky Criminal Law on Hate Crime, incitement to Hatred and Hate Speech in OSCE Participating States.

- OSCE 2009 Hate Crime Laws.

- International Covenant on Civil and Political Rights (International Covenant on Civil and Political Rights / ICCPR.

\footnotetext{
8 Paschal Marvin 2014 Freedom of Social Media in Indonesia https://www.academia.edu/29486702/Kebebasan Berpendapat Melalui Media Sosial di Indonesia Accessed on January 182018.

${ }^{9}$ Frank William La Rue 2011 UN report: Internet access is a human right http://latimesblogs.latimes.com/technology/2011/06/united-nations-report-internet-access-is-ahumanright. html \# accessed on June 212018.

${ }^{10}$ Yanuar Nugroho et al. 2012 Mapping the Landscape of the Media Industry in Contemporary Indonesia http://kalamkata.org/2011/02/20/pedomanberekspresi-online/?did=39 accessed on June 252018.

11 Walker Samuel Hate Speech: The History of an American Controversy Jakarta: NE: University of Nebraska Press p. 39.
} 
The national commission for human rights (KOMNASHAM) in speech handling hate pocket book (Hate Speech) speech expressing hatred (Hate Speech) is very dangerous, because: ${ }^{12}$

- Degrading another human being.

Humans are creatures of God and no one was entitled to reduce human beings and humanity of anyone who is God's creation.

- Give rise to material losses and human casualties.

The research data pointed amount of material losses and victims of identity-based violence is greater than other violence.

- Could have an impact on the conflict.

Incitement to hostile person or group can lead to conflict, this conflict can be between individuals and extends into communal or inter-group conflict.

- Distroying could have an impact on the group (genocide)

Hate speech can make stereotyping / labeling, stigma, exclusion, discrimination, violence. At its most terrible could antagonize collective genocide, burning villages or destruction (genocide) against the target groups who hatred.

It was also stated that the speech of hatred (hate speech) it can be done through a variety of media, including in speeches campaign activities; banners or banners; social media networks; delivery of public opinion (demonstration); religious lecture; print and electronic media as well as pamphlets. To handle acts of hate speech in order to not create discrimination, violence, disappearances lives, and / or social conflict that extends the necessary measures, namely the handling of preventive and repressive action.

Police preventive measures which are presumably can be done by, among others:

- First, any police personnel are expected to have an understanding and knowledge about the forms of hatred.

- Second, the police personnel are expected to be more responsive or sensitive to the symptoms in people who are potentially a criminal offense.

- Third, any police personnel conducting the analysis or assessment of the situation and the conditions in the environment. Especially with regard to acts of hate speech.

- Fourth, every police personnel to report to the chairman of each of the circumstances in the environment, particularly with regard to acts of hate speech.

If found acts that potentially leads to criminal acts of hate speech, then every member of the Police shall take action, among others:

- Monitor and detect the early onset of seeds of dissension in the community.

- To approach the alleged conduct of hate speech.

- Reconciling the alleged conduct with the victim of hate speech of hate speech.

- Finding a solution for peace between the warring parties and provide insight into the impact that will result from the speech of hatred in society.

If in practice Preventive measures can not solve the problem, there was a way of law enforcement by referring to:

- Penal Code Article 156 of the Criminal Code, Article 157 of the Criminal Code, Article 310 of the Criminal Code, Article 311 of the Criminal Code.

- Article 28 and Article 45 paragraph (2) of the Law on Information and Electronic Transactions.

\footnotetext{
${ }^{12}$ KOMNASHAM RI 2015 Penanganan Ujaran Kebencian (hate speech) KOMNASHAM Jakarta p. 3.
} 
- Article 16 of Act No. 40 of 2008 on the Elimination of Racial and Ethnic Discrimination.

- Act No. 7 of 2012 on Social Conflict Management.

- Police Chief Regulation of the Republic of Indonesia Number 8 Of 2013 on Technical Management of Social Conflict.

However, in practice the Police often encounter obstacles in the handling of the offenses relating to hate speech. Various attempts have been made, but has not been able to provide a deterrent effect to the perpetrators. So the police chief police chief has issued Circular No. SE / 6 / X / 2015 as an effort to fill the legal vacuum because there is no effort from the government to make rules that specifically regulate the speech of hatred or hate speech.

With the publication of the Chief of Police Circular Letter No. SE / 6 / X / 2015, the Police have guidelines in the act when dealing with cases of hate speech. INP is no longer hesitant to act and be able to sort out what is called a hatred speech and what is not. Interest issuance of Circular (SE) Handling Hate Speech is for the handling problems which increasingly widespread hatred and less anticipated by the police, in particular from the lowest level. Circular of Hate Speech is a technical guide police officers from the lowest level, in order to: ${ }^{13}$

- Realizing the dangers of hate speech, both the unity and integrity, as well as to the protection of minorities.

- Being able to detect symptoms of hate speech is rampant in society.

- Being able to take appropriate measures, both preventive and enforcement, to overcome hatred speech, using the authority possessed as well as criminal law provisions.

In the case of hate speech, preferably using preventive measures, even after the complaint of the victim was also conducted mediation efforts first. Thus, the Police action as stipulated in Circular of Hate Speech is to align with the attitude acts as a series of translation of values, to create, maintain, and maintaining social peace alive. This is in accordance with the principal task of the Police sebagiamana forth in Article 13 of Act No. 2 of 2002 which states that the Police has the main task, namely:

- Maintaining security and public order.

- Enforcing the law.

- Provide protection, shelter and services to the community.

Thus, Role of the Police in dealing with the proliferation occur speech of hatred (hate speech), especially occurring in cyberspace, can have a positive impact for the survival of the nation and state.

\section{Closing}

\subsection{Conclusion}

Based on the discussion presented regarding the formulation of the problem, then the conclusion can be stated as follows:

- In addressing the increasingly widespread occurrence of criminal acts of hate speech

\footnotetext{
${ }^{13}$ Christian Chrisye Lolowang "Implementasi Surat Edaran Kapolri Nomor SE/06/X/2015 Tentang Penanganan Ujaran Kebencian (hate speech) Dalam Penegakan Hukum Di Polres Jakarta Selatan" Jurnal Reformasi Hukum Vol. 1. No. 1 September 2017 p. 63-63.
} 
(hate speech) as a result of advances in technology, it takes the role of the Preventive Police began efforts to enforce the law / repressive with reference to the rule of law in Indonesia.

- Any form of restriction of freedom of speech on social media in Indonesia, namely the prohibition to disseminate classified payload or content of hate speech and the dissemination of false news, especially to harm others and dividing the nation.

\subsection{Suggestion}

- The government should put forward the preventive measures (prevention) in addressing the rampant cases of hate speech and hoaxes in cyberspace, especially the millennial generation that has a high level of dependence on social media.

- Law enforcement should be assertive and pro-active in dealing with cases of hate speech and hoaxes on social media, especially with regard to the integrity of the state and public concern.

\section{Bibliography}

[1] KOMNASHAM RI 2015 Penanganan Ujaran Kebencian (hate speech) Jakarta: KOMNASHAM.

[2] Lolowang Christian Chrisye. 2017. “Implementasi Surat Edaran Kapolri Nomor SE/06/X/2015 Tentang Penanganan Ujaran Kebencian (hate speech) Dalam Penegakan Hukum Di Polres Jakarta Selatan" Jurnal Reformasi Hukum Vol. 1. No. 1.

[3] La Rue Frank William. 2011 U.N. report: Internet access is a human right url: http://latimesblogs.latimes.com/technology/2011/06/united-nations-reportinternet-access-is-a-humanright. Html.

[4] Marvin Paskalis 2014 Kebebasan Berpendapat melalui Media Sosial di Indonesia, url:https://www.academia.edu/29486702/Kebebasan_Berpendapat Mel alui Media Sosial di Indonesia.

[5] Nugroho Yanuar dkk. 2012 Mapping the Landscape of Media Industry in Contemporary Indonesia url: http:// kalamkata.org/2011/02/20/ pedomanberekspresi-online/?did=39.

[6] Ramli Ahmad M. 2004. Cyber Law dan HAKI dalam Sistem Hukum Indonesia Jakarta: Rafika Aditama.

[7] Raharjo Agus. 2002. Pemahaman Dan Upaya Upaya Pencegahan Berteknologi Bandung: Citra Aditya Bakti Bandung.

[8] Suhariyanto Budi. 2014. Tindak Pidana Teknologi Informasi (CYBERCRIME) Jakarta: Raja Grafindo Persada.

[9] Samuel Walker. 2018 Hate Speech: The History of an American Controversy Jakarta: NE: University of Nebraska Press.

[10] Act No. 2 of 2002 on the Indonesian National Police.

[11] Act No. 12 of 2005 concerning the Ratification of the International Covenant On Civil Rights and Politics.

[12] Act No. 11 of 2008 on Information And Electronic Transactions. 